Article

\title{
Contribution to the Knowledge on Distribution of Tardigrada in Turkey
}

\author{
Duygu Berdi *(D) and Ahmet Altındağ \\ Department of Biology, Faculty of Science, Ankara University, 06100 Ankara, Turkey; \\ altindag@science.ankara.edu.tr \\ * Correspondence: duyguberdi@gmail.com
}

Received: 28 December 2019; Accepted: 4 March 2020; Published: 6 March 2020

\begin{abstract}
Tardigrades have been occasionally studied in Turkey since 1973. However, species number and distribution remain poorly known. In this study, distribution of Tardigrades in the province of Karabük, which is located in northern coast (West Black Sea Region) of Turkey, was carried out. Two moss samples were collected from the entrance of the Bulak (Mencilis) Cave. A total of 30 specimens and 14 eggs were extracted. Among the specimens; Echiniscus granulatus (Doyère, 1840) and Diaforobiotus islandicus islandicus (Richters, 1904) are new records for Karabük. Furthermore, this study also provides a current checklist of tardigrade species reported from Turkey, indicating their localities, geographic distribution and taxonomical comments.
\end{abstract}

Keywords: cave; Diaforobiotus islandicus islandicus; Echiniscus granulatus; Karabük; Tardigrades; Turkey

\section{Introduction}

Caves are not only one of the most important forms of karst, but also one of the most unique forms of karst topography in terms of both size and formation characteristics, which are formed by mechanical melting and partly chemical erosion of water [1]. Most of the caves in Turkey were developed within the Cretaceous and Tertiary limestone, metamorphic limestone [2], and up to now ca. 40000 karst caves have been recorded in Turkey. Although, most of these caves are found in the karstic plateaus zone in the Toros System, important caves, such as Kızılelma, Sofular, Gökgöl and Mencilis, have also formed in the Western Black Sea [3].

Some invertebrate communities can adapt well to these interesting underground formations, whose habitats are found rarely on earth [4,5]. Tardigrades, also known as water bears, are microscopic invertebrates that are one of these invertebrates that can survive in this environment with its harsh conditions. In general, tardigrades inhabit marine, freshwater and terrestrial environments (deserts, soil and leaf litters, mosses, lichens and liverworts, underground and marine caves throughout the world [6,7]. Until now, 30 families, 142 genera and nearly 1300 tardigrade species and 34 subspecies have been reported worldwide [8].

The tardigrade fauna of Turkey remains poorly known [9], with only few papers published since 1973. The most comprehensive studies were carried out by Maucci [10-16], Morgan [17], Binda [18], Kaczmarek et al. [9], Kharkevych and Sergeeva [19] and Ürkmez et al. [20]. To date 54 species and one subspecies have been reported from Turkey. Among them, eleven species and one subspecies belong to the genus Echiniscus C.A.S Shultze, 1840 [21] whereas only one species belongs to the genus Diaforobiotus Guidetti, Rebecchi, Bertolani, Jönsson, Kristensen and Cesari, 2016 [22].

This paper reports two tardigrade species, which were discovered for the first time from the Bulak (Mencilis) Cave, in Karabük. In addition, we also provide a full checklist of tardigrade species reported from Turkey with their localities, geographic distributions and taxonomical comments. 


\section{Materials and Methods}

In March 2017, two moss samples were collected from the entrance of Bulak (Mencilis) Cave $\left(41^{\circ} 16^{\prime} 30.1836^{\prime \prime} \mathrm{N} ; 32^{\circ} 37^{\prime} 28.4628^{\prime \prime} \mathrm{E}\right)$, which is located nearly $8.5 \mathrm{~km}$ northwest of Safranbolu, the largest and most developed province of Karabük [23]. Bulak (Mencilis) Cave is the fourth largest cave in Turkey with a length of approximately $6 \mathrm{~km}[24,25]$.

One moss sample was collected from a rock which was found around the entrance of the Cave and the other from the wall of the entrance. Both samples were put into paper bags and let dry in the laboratory. They were later examined for terrestrial tardigrades using a standard method described by Dastych [26] with modifications described by Stec and Smolak [27]. The samples were placed in a beaker for rehydration with tap water in the laboratory. One day later after stirring, the water containing moss particles were poured into a $200 \mathrm{ml}$ cylinder. After precipitation, approximately $50 \mathrm{ml}$ of remaining sediment was taken into a glass petri dish. Tardigrades and eggs were placed from the sediment under the stereomicroscope (Leica MZ16 A). Tardigrades and their eggs were mounted on microscopic slides in Hoyer's medium and observations and the photomicrographs were made using a phase-contrast microscope (Zeiss Axio Imager M1). The species were identified using the monograph published by Ramazotti and Maucci [7] and according to Guidetti et al. [22]. For genus abbreviations we referred to Perry et al. [28]. All slides, which were secured with a transparent nail polish, were stored in the Ankara University, Department of Biology, Aquatic Animals Research Laboratory.

\section{Results}

In total, 30 specimens and 14 eggs were found. Within those specimens, 10 belong to the genus Paramacrobiotus Guidetti, Schill, Bertolani, Dandekar and Wolf, 2009 [29] and they have not been identified to species level due to the absence of eggs. The remaining 20 specimens and 14 eggs were identified as Ech. granulatus (Doyère, 1840) [30] and Dia. i. islandicus (Richters, 1904) [31], which are new records for the province of Karabük.

\section{Taxonomic Accounts}

Phylum: Tardigrada Spallanzani, 1777 [32]

Class: Heterotardigrada Marcus, 1927 [33]

Order: Echiniscoidea Richters, 1926 [34]

Family: Echiniscidae Thulin, 1928 [35]

Genus: Echiniscus C.A.S. Schultze, 1840 [21]

Echiniscus granulatus (Doyère, 1840) [30]

Material examined: Seven specimens.

Remarks: It has dorsal sculpture of polygonal shape (Figure 1C) that is composed of granules. Lateral appendices cirri $A, C$ and $D$ present (Figure 1A,B), which are in the form of long filaments, lateral cirri $B$ absent. Cirri $E$ in shape of spines. The dorsal appendices $C^{d}$ and $D^{d}$ as long spines. Fourth pair of legs with dentate collar (Figure 1D). All characteristics properties of this species correspond with the description in Ramazotti and Maucci [7]. The species is known from many localities in Europe, Turkey, North America, Africa and Asia [36].

Type locality: France [7] 


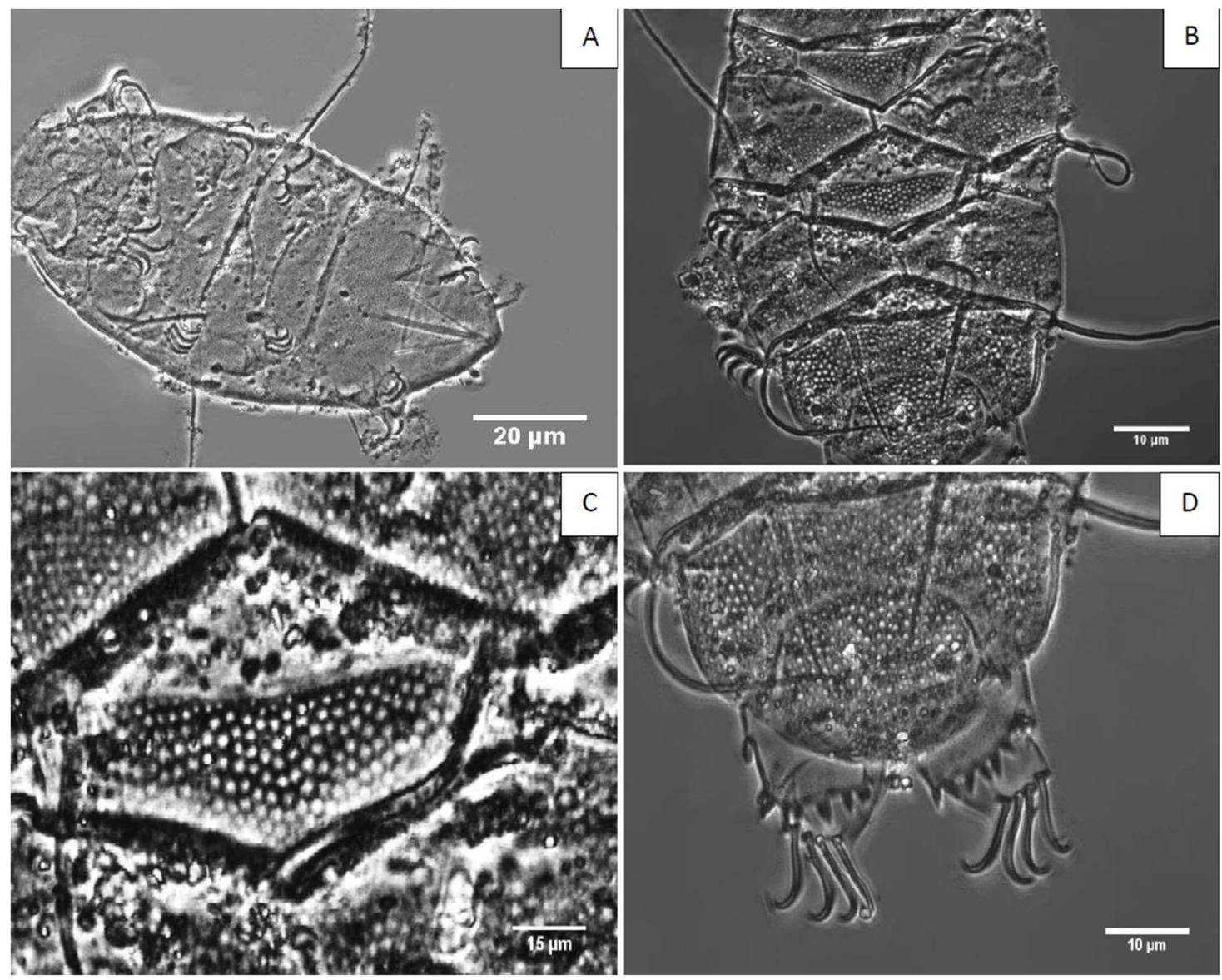

Figure 1. Echiniscus granulatus: (A) Habitus, (B) dorsal plates, (C) detail of the cuticular ornamentation, (D) claws of the fourth pair of legs; using phase contrast microscopy.

Class: Eutardigrada Richters, 1926 [34]

Order: Macrobiotoidea Guil, Jørgensen and Kristensen, 2019 [37]

Family: Richtersiidae Guidetti, Rebecchi, Bertolani, Jönsson, Kristensen and Cesari, 2016 [22]

Genus: Diaforobiotus Guidetti, Rebecchi, Bertolani, Jönsson, Kristensen and Cesari, 2016 [22]

Diaforobiotus islandicus islandicus (Richters, 1904) [31]

Material examined: In total 13 specimens and 14 eggs.

Remarks: Their body length is varied from 550 to $665 \mu \mathrm{m}$ (Figure 2A). Buccal tube is thin and pharynx oval with two macroplacoids (Figure 2B); the first is longer than the second. Lunulas present and dentate (Figure 2C). The projections of the eggs are thin cones, almost spine-like (Figure 2D). Measurements of selected morphological characters for the smallest and largest examined specimens are given in Table 1. All characteristics properties of the species correspond with the description in Guidetti et al. [22]. Diaforobiotus i. islandicus (Richters, 1904) [31] was reported in Italy, Switzerland, Crete, Carpathians, Sweden, Norway, Iceland, Faroe Islands, Spitzbergen Archipelago, Greenland, America and Turkey $[7,36]$ 


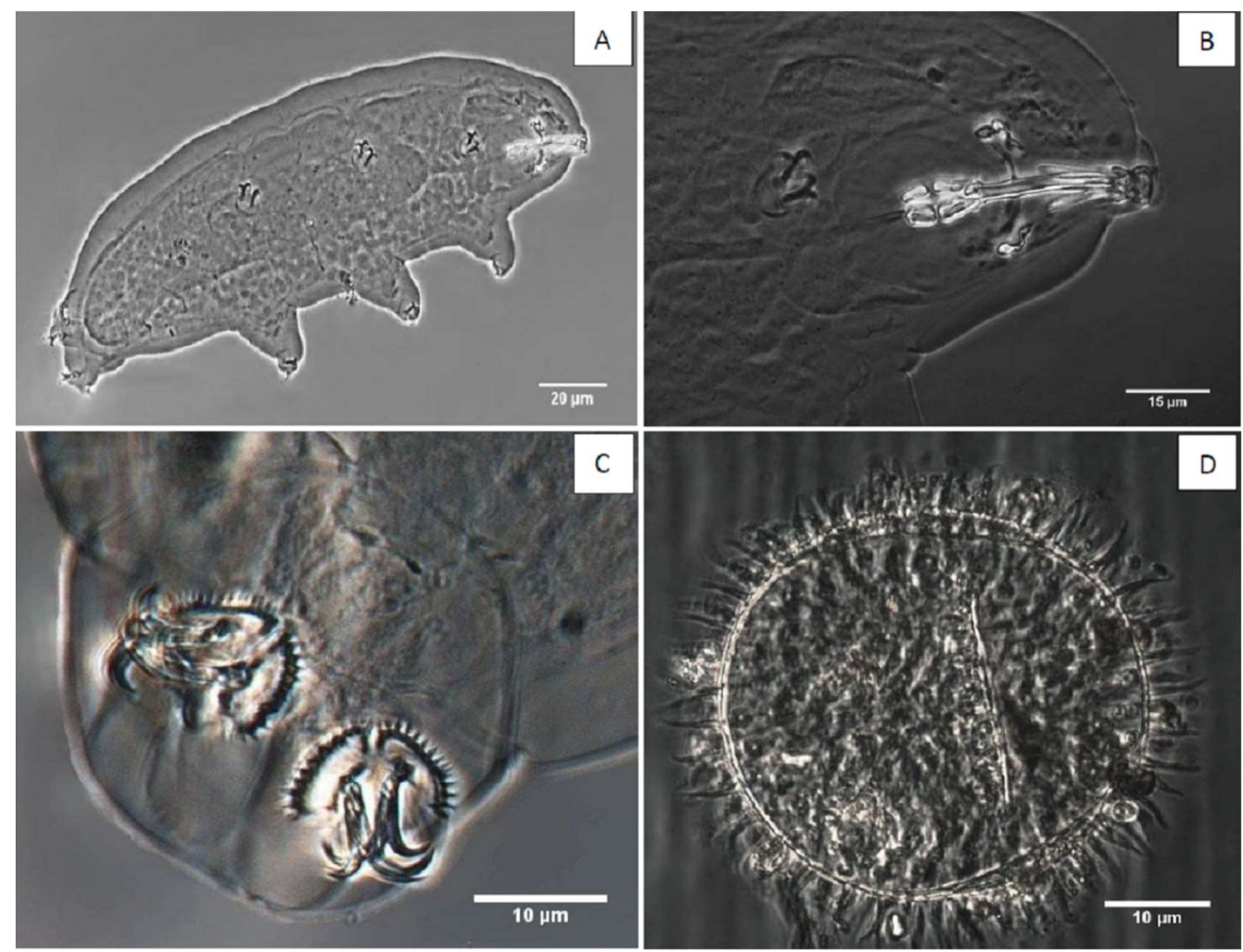

Figure 2. Diaforobiotus islandicus islandicus: (A) Habitus, (B) bucco-pharyngeal apparatus (lateral view), (C) claws of legs IV with large dentate lunula, (D) egg shell (midsection); using phase contrast microscopy.

Table 1. Measurements of selected morphological characters of largest and smallest specimens of Dia. $i$. islandicus and eggs (all values in $\mu \mathrm{m}, p t$ ratios in brackets).

\begin{tabular}{ccc}
\hline Character & Smallest Specimen & Largest Specimen \\
\hline Body & 550 & 665 \\
Buccal tube length & 56.0 & 62.0 \\
Buccal tube external width & $4.2[7.5]$ & $5.2[8.4]$ \\
Buccal tube internal width & $2.0[3.6]$ & $2.3[3.7]$ \\
Stylet support insertion point & $16.9[30.2]$ & $21.8[35.2]$ \\
Macroplacoid row & $13.4[23.9]$ & $20.0[32.3]$ \\
First macroplacoid & $5.8[10.4]$ & $9.3[15.0]$ \\
Second macroplacoid & $4.0[7.1]$ & $6.7[10.8]$ \\
External claw I & $9.0[16.1]$ & $13.2[21.3]$ \\
Internal claw I & $14.5[25.9]$ & $18.7[30.2]$ \\
External claw II & $9.9[17.7]$ & $14.0[22.6]$ \\
Internal claw II & $15.2[27.1]$ & $22.3[36.0]$ \\
External claw III & $10.7[19.1]$ & $14.3[23.1]$ \\
Internal claw III & $16.1[28.8]$ & $23.0[37.1]$ \\
External claw IV & $15.8[28.2]$ & $18.1[29.2]$ \\
Internal claw IV & $22.6[40.4]$ & $25.7[41.5]$ \\
\hline Egg diameter without processes & 94 & 103 \\
Diameter with processes & 133 & 140 \\
Process height & $9.6-11.7$ & $11.9-12.1$ \\
\hline
\end{tabular}

Type locality: Iceland [7] 
With our study, we added Karabük to the provinces in Turkey in which tardigrades have been recorded and thus, increased the number from 31 to 32 (see Figure 3 and Table 2 for details).

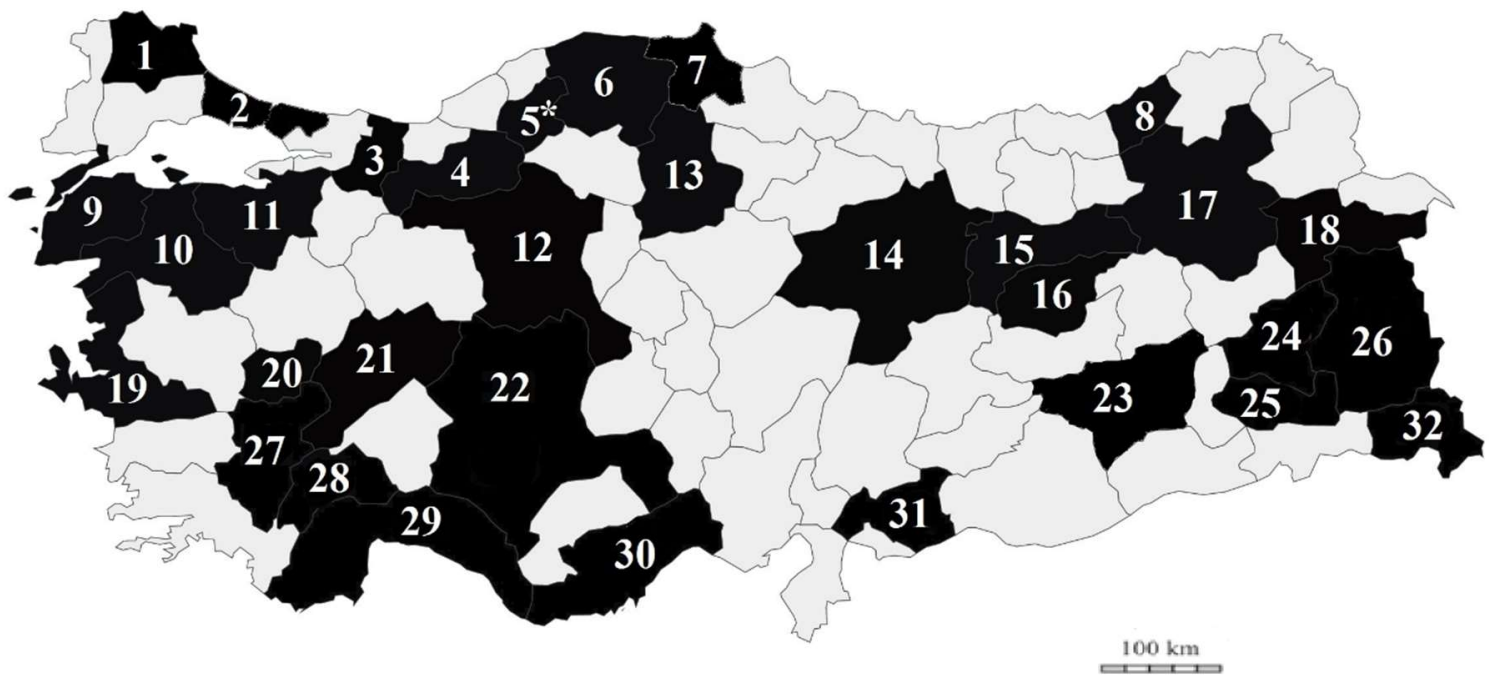

Figure 3. The map of Turkey including all tardigrade species were reported from 32 provinces (marked in dark) From left to right: 1-Kırklareli, 2-İstanbul, 3-Sakarya, 4-Bolu, 5-Karabük *, 6-Kastamonu, 7-Sinop, 8-Rize, 9-Çanakkale, 10-Balıkesir, 11-Bursa, 12-Ankara, 13-Çorum, 14-Sivas, 15-Erzincan, 16-Tunceli, 17-Erzurum, 18-Ağrı, 19-İzmir, 20-Uşak, 21-Afyonkarahisar, 22-Konya, 23-Diyarbakır, 24-Bitlis, 25-Siirt, 26-Van, 27-Denizli, 28-Burdur, 29-Antalya, 30-Mersin, 31-Gaziantep, 32-Hakkari. Kaczmarek et al. [9]'s map is revised by adding the new provinces according to new records. ${ }^{*}$ New province, which was added to the map with present study.

Table 2. The final list of all reported tardigrade species (marine and terrestrial) from Turkey.

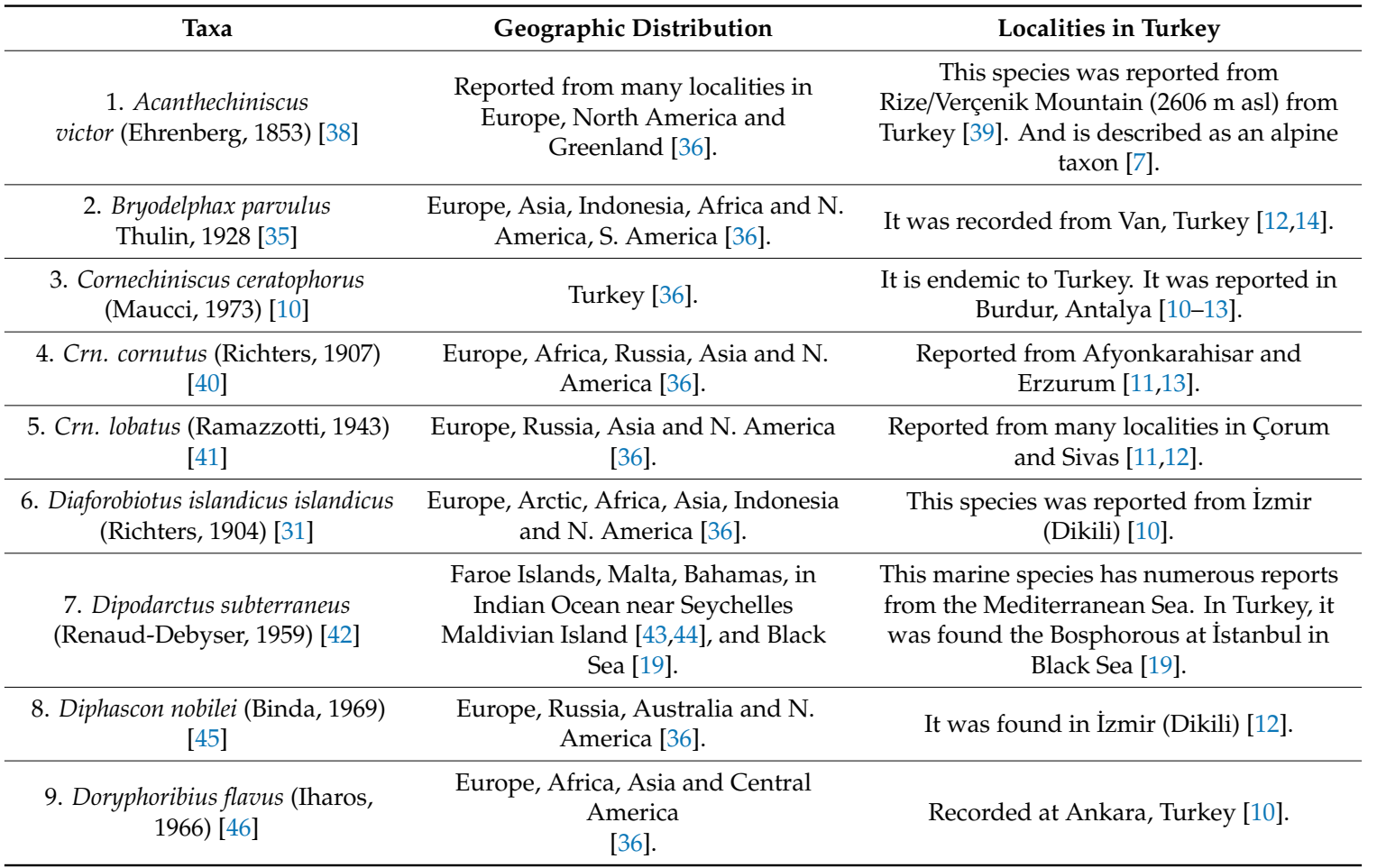


Table 2. Cont.

\begin{tabular}{|c|c|c|}
\hline Taxa & Geographic Distribution & Localities in Turkey \\
\hline $\begin{array}{l}\text { 10. Echiniscus blumi blumi Richters, } \\
1903 \text { [47] }\end{array}$ & $\begin{array}{l}\text { Reported from a few localities in } \\
\text { Europe (Italy, Spain, Scotland, } \\
\text { Switzerland, Turkey, Hungary, Greece) } \\
\text { and N. America [36]. }\end{array}$ & $\begin{array}{c}\text { It was reported from Ankara, Erzincan, and } \\
\text { Van, Turkey [10,12,16]. As Ech. blumi blumi } \\
\text { and as Ech. mediantus Marcus, } 1930 \text { [48] } \\
\text { which is synonym of Ech. blumi blumi } \\
\text { according to Gasiorek et al. [49]. }\end{array}$ \\
\hline $\begin{array}{l}\text { 11. Ech. canadensis Murray, } 1910 \\
\text { [50] }\end{array}$ & $\begin{array}{c}\text { Europe, Africa, Asia, North and South } \\
\text { America [36]. }\end{array}$ & $\begin{array}{c}\text { It was reported from many localities from } \\
\text { Turkey. Afyonkarahisar, Ağrı, Ankara, } \\
\text { Bitlis, Çanakkale, Erzincan, İzmir, Kırklareli, } \\
\text { Uşak, Van [10-12,16]. }\end{array}$ \\
\hline $\begin{array}{l}\text { 12. Ech. columinis Murray, } 1911 \\
\text { [51] }\end{array}$ & Europe and China [36]. & $\begin{array}{l}\text { This palearctic species. It was only reported } \\
\text { from Küçükkuyu/Çanakkale, Turkey [12]. }\end{array}$ \\
\hline 13. Ech. dikenli Maucci, 1973 [10] & Turkey [36]. & $\begin{array}{l}\text { This endemic species was originally } \\
\text { collected in Afyonkarahisar, Turkey [10-12]. }\end{array}$ \\
\hline $\begin{array}{l}\text { 14. Ech. granulatus (Doyère, 1840) } \\
\text { [30] }\end{array}$ & $\begin{array}{c}\text { Europe, Africa, Asia, Indonesia and N. } \\
\text { America [36]. }\end{array}$ & $\begin{array}{l}\text { This species, reported from mountain and } \\
\text { submountain regions [52] has been recorded } \\
\text { from Bolu, Burdur, Çorum, Erzurum, } \\
\text { Kastamonu, Sivas, Van [10-12,14], and now, } \\
\text { in addition, from Karabük (this study). }\end{array}$ \\
\hline $\begin{array}{l}\text { 15. Ech. merokensis merokensis } \\
\text { Richters, } 1904 \text { [53] }\end{array}$ & $\begin{array}{l}\text { Europe, Africa, Asia, Russia, N. } \\
\text { America and S. America [36]. }\end{array}$ & It was reported from İzmir, Turkey $[10,12]$. \\
\hline $\begin{array}{l}\text { 16. Ech. merokensis suecicus Thulin, } \\
1911 \text { [54] }\end{array}$ & $\begin{array}{l}\text { Reported from many localities in } \\
\text { Europe, Africa and N. America [36]. }\end{array}$ & $\begin{array}{l}\text { Reported from Bursa/Uludağ Mountain at } \\
2200 \mathrm{~m} \text { asl }[10,12] .\end{array}$ \\
\hline 17. Ech. osellai Maucci, 1975 [11] & Turkey [36]. & $\begin{array}{l}\text { This endemic species has only reported } \\
\text { from Antalya, Turkey }[11,12] .\end{array}$ \\
\hline 18. Ech. testudo (Doyère, 1840) [30] & $\begin{array}{l}\text { Europe, Africa, Asia, N. America and } \\
\text { S. America }[9,12,36,55,56] \text {. }\end{array}$ & $\begin{array}{l}\text { It is cosmopolitan species. It was found in } \\
\text { several localities in Afyonkarahisar, Ağrı, } \\
\text { Antalya, Bitlis, Burdur, Çorum, Denizli, } \\
\text { Diyarbakır, Erzincan, Erzurum, Gaziantep, } \\
\text { Hakkari, Kastamonu, Mersin, Siirt, Sivas, } \\
\text { Van and Konya, Turkey }[10,11,17] .\end{array}$ \\
\hline $\begin{array}{l}\text { 19. Ech. trisetosus Cuénot, } 1932 \\
\text { [57] }\end{array}$ & $\begin{array}{c}\text { Europe, Africa, Asia and N. America } \\
\text { [36]. }\end{array}$ & $\begin{array}{c}\text { It was reported from Afyonkarahisar, Ağrı, } \\
\text { Ankara, Balıkesir, Çanakkale, Çorum, } \\
\text { Diyarbakır, Erzurum, Hakkari, İzmir, } \\
\text { Kırklareli, Siirt, Uşak, Van, Turkey } \\
\text { [10-12,16,17]. }\end{array}$ \\
\hline 20. Ech. trojanus Maucci, 1973 [10] & Turkey [36]. & $\begin{array}{l}\text { This endemic species } \backslash \text { was originally } \\
\text { reported from Çanakkale, İzmir, Turkey } \\
\text { [10-12]. }\end{array}$ \\
\hline $\begin{array}{l}\text { 21. Grevenius sismicus (Maucci, } \\
\text { 1978) [12] }\end{array}$ & Turkey and India [36]. & It was reported from Van, Turkey $[12,14]$ \\
\hline $\begin{array}{l}\text { 22. Hypsibius convergens } \\
\text { (Urbanowicz, 1925) [58] }\end{array}$ & $\begin{array}{l}\text { Reported from many localities all over } \\
\text { the world [36]. }\end{array}$ & $\begin{array}{c}\text { This cosmopolitan species group requires } \\
\text { the majority of records to be confirmed } \\
{[9,59] \text {. It has been reported from İzmir, }} \\
\text { Turkey }[11,12] .\end{array}$ \\
\hline 23. Hys. microps Thulin, 1928 [35] & $\begin{array}{l}\text { Widespread throughout the world } \\
\text { [36]. }\end{array}$ & $\begin{array}{l}\text { This species is considered cosmopolitan, but } \\
\text { a species group the majority of records need } \\
\text { to be confirmed }[9,59] \text {. It has been reported } \\
\text { from İzmir and Mersin, Turkey }[11,12] \text {. }\end{array}$ \\
\hline $\begin{array}{l}\text { 24. Isohypsibius macrodactylus } \\
\text { (Maucci, 1978) [12] }\end{array}$ & $\begin{array}{c}\text { Italy, Turkey, Cyprus, Caucasus and } \\
\text { Africa }[36,60] .\end{array}$ & $\begin{array}{l}\text { A holarctic species was reported from Ağrı } \\
\text { and Van, Turkey }[9,12,14,36] .\end{array}$ \\
\hline $\begin{array}{l}\text { 25. Iso. prosostomus Thulin, } 1928 \\
\text { [35] }\end{array}$ & $\begin{array}{l}\text { Reported from many localities in } \\
\text { Europe, Russia, Africa, Indonesia, N. } \\
\text { America and S. America [36]. }\end{array}$ & $\begin{array}{l}\text { Considered cosmopolitan, this species need } \\
\text { to be re-described [9]. Reported from } \\
\text { Ankara, Bolu, İzmir, Erzincan and } \\
\text { Kastamonu, Turkey [10-12]. }\end{array}$ \\
\hline $\begin{array}{l}\text { 26. Itaquascon placophorum Maucci, } \\
1973 \text { [10] }\end{array}$ & A few localities from Europe [36]. & $\begin{array}{c}\text { It was originally described from Ankara } \\
\text { and Sakarya, Turkey [10-12]. }\end{array}$ \\
\hline
\end{tabular}


Table 2. Cont.

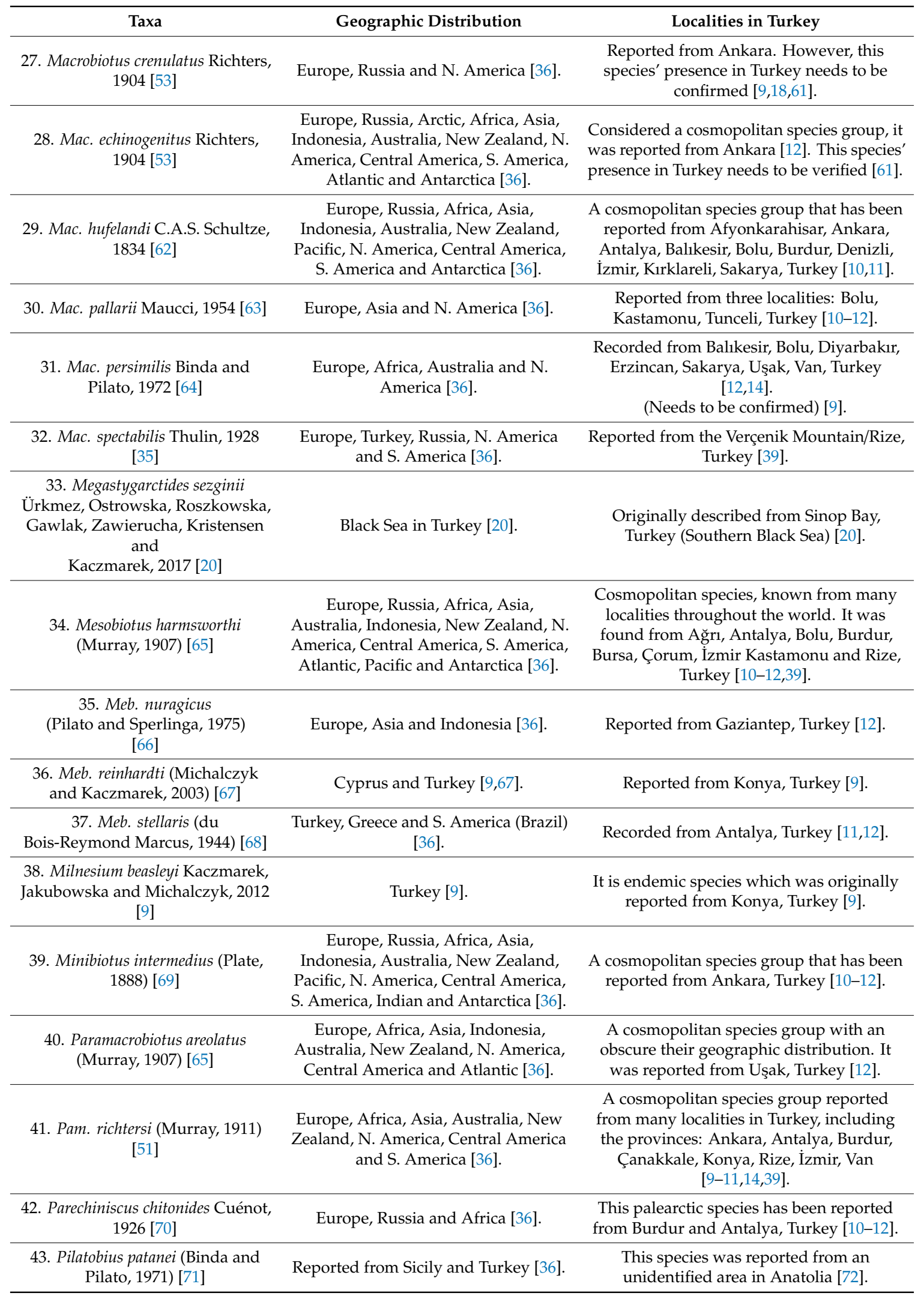


Table 2. Cont.

\begin{tabular}{|c|c|c|}
\hline Taxa & Geographic Distribution & Localities in Turkey \\
\hline $\begin{array}{l}\text { 44. Pseudechiniscus facettalis } \\
\text { Petersen, } 1951 \\
\text { [73] }\end{array}$ & $\begin{array}{l}\text { Europe, Africa, New Zealand, N. } \\
\text { America and S. America [36]. }\end{array}$ & Reported from İzmir, Turkey [10-12]. \\
\hline $\begin{array}{l}\text { 45. Pse. megacephalus Mihelčič, } \\
1951 \text { [74] }\end{array}$ & Turkey and Austria [36]. & Only reported from Ankara, Turkey [10-12]. \\
\hline $\begin{array}{l}\text { 46. Pse. ramazottii ramazzottii } \\
\text { Maucci, } 1952 \text { [75] }\end{array}$ & $\begin{array}{l}\text { Europe, Russia, North and South } \\
\text { America [36]. }\end{array}$ & $\begin{array}{c}\text { Recorded from the Verçenik Mountain/Rize, } \\
\text { Turkey [39]. }\end{array}$ \\
\hline $\begin{array}{l}\text { 47. Pse. suillus (Ehrenberg, 1853) } \\
\text { [38] }\end{array}$ & $\begin{array}{c}\text { Europe, Arctic, Africa, Asia, Indonesia, } \\
\text { Indian, Australia, New Zealand, } \\
\text { Pacific, N. America, Canada, Central } \\
\text { America, S. America and Antarctica } \\
\text { [36]. }\end{array}$ & $\begin{array}{l}\text { Described as a cosmopolitan species group, } \\
\text { this species was reported from Ankara and } \\
\text { İzmir, Turkey [10]. }\end{array}$ \\
\hline $\begin{array}{l}\text { 48. Ramazzottius oberhaeuseri } \\
\text { (Doyère, 1840) [30] }\end{array}$ & $\begin{array}{l}\text { Europe, Greenland, the Arctic and } \\
\text { Antarctic, North and South America, } \\
\text { Africa and New Zealand [36]. }\end{array}$ & $\begin{array}{l}\text { A cosmopolitan species group that has been } \\
\text { reported, from numerous locations in } \\
\text { Turkey, including the provinces: } \\
\text { Afyonkarahisar, Ağr1, Ankara, Antalya, } \\
\text { Bolu, Çorum, Erzincan, Erzurum, Hakkari, } \\
\text { Gaziantep, Kastamonu, Kırkareli, Uşak, } \\
\text { Konya, Tunceli, Van and Rize [9-12,17,39]. } \\
\text { However older records of this species need } \\
\text { to be verified [9]. }\end{array}$ \\
\hline $\begin{array}{l}\text { 49. Richtersius coronifer (Richters, } \\
\text { 1903) [47] }\end{array}$ & $\begin{array}{l}\text { Europe, Arctic, Africa, Asia, N. } \\
\text { America and S. America [36]. }\end{array}$ & $\begin{array}{l}\text { Reported from Ağr1, Çorum, İzmir and Van, } \\
\text { Turkey }[11,14] .\end{array}$ \\
\hline $\begin{array}{l}\text { 50. Tanarctus ramazzottii } \\
\text { Renaud-Mornant, } 1975 \text { [76] }\end{array}$ & $\begin{array}{l}\text { Gulf of Biscaglia, Coast of Britain, } \\
\text { Mediterranean Sea [7,43] and Black } \\
\text { Sea in Turkey [19]. }\end{array}$ & $\begin{array}{l}\text { In Turkey, it has been reported from the } \\
\text { Bosphorus of İstanbul in the Black Sea [19]. }\end{array}$ \\
\hline $\begin{array}{l}\text { 51. Tenuibiotus hystricogenitus } \\
\text { (Maucci, 1978) [12] }\end{array}$ & Turkey, Germany, Greece [36]. & $\begin{array}{l}\text { It was recorded from Çorum and Erzurum, } \\
\text { Turkey [12]. }\end{array}$ \\
\hline $\begin{array}{l}\text { 52. Ursulinius duranteae (Maucci, } \\
\text { 1978) [12] }\end{array}$ & Turkey [36]. & $\begin{array}{l}\text { This endemic species was originally } \\
\text { reported from Ağrı, Erzurum and } \\
\text { Gaziantep, Turkey [12]. }\end{array}$ \\
\hline 53. Urs. josephi (Iharos, 1964) [77] & Europe [36]. & $\begin{array}{l}\text { It was only recorded from Van, Turkey } \\
\qquad[12,14] .\end{array}$ \\
\hline $\begin{array}{l}\text { 54. Urs. leithaicus (Iharos, 1966) } \\
\text { [46] }\end{array}$ & $\begin{array}{l}\text { A few localities in Europe (Austria, } \\
\text { Finland, Hungary) and Turkey [36]. }\end{array}$ & Reported from Van, Turkey [12]. \\
\hline $\begin{array}{l}\text { 55. Urs. torulosus (Mihelčič, 1959) } \\
\text { [78] }\end{array}$ & Turkey and Austria [36]. & Reported from İzmir, Turkey $[11,12]$. \\
\hline
\end{tabular}

\section{Discussion}

We found Dia. i. islandicus (Richters, 1904) [31] in the province of Karabük, which is located in the Black Sea Region. It had previously been reported from İzmir, located in the Aegean Region of Turkey. This species has been identified from many localities in Europe, Africa, Indonesia, and North America [36].

Generally associated with limestone and alkaline bedrock, Ech. granulatus (Doyère, 1840) [30] has been reported from many localities in Europe, Africa, Caucasus, Georgia, Asia, Indonesia and North America [10-12,14,36,79]. Before our study, it had previously been reported from the provinces of Burdur, Bolu, Çorum, Erzurum, Kastamonu, Sivas, and Van in Turkey [36]. In the Poland, the species has been reported as a mountainous and sub-mountainous species and recorded between 500 and $1000 \mathrm{~m}$ asl on alkaline bedrocks [52]. In Turkey, this species was found in Çeltikçi Beli, Ilgaz Mountain, Boğazkale, Y1ldizeli and Horasan regions [12]. Mostly usually recorded from $1000 \mathrm{~m}$ asl or above [10], this species has also been reported from the Trestede Karst plateau, in Italy, at between 200 to $300 \mathrm{~m}$ asl [10].

Although taxonomic and biogeographic studies on caves harboring tardigrades have been conducted for many years, there is still poor knowledge of their patterns of diversity. Only a 
few published papers center upon investigation for cave tardigrades. In 1996, Astatumen trinacriae (Arcidiacono, 1962) [80] was collected from the entrance of a cave located in Menglun, China [81]. Doryphoribius smokiensis Bartels, Nelson, Kaczmarek and Michalczyk, 2007 [82], Dor. longistipes Bartels, Nelson, Kaczmarek and Michalczyk, 2008 [83], and Dor. minimus Bartels, Nelson, Kaczmarek and Michalczyk, 2008 [83] were reported from the caves in the Great Smoky Mountains National Park in North America. In 2008, Minibiotus formosus Zawierucha, Dziamięcki, Jakubowska, Michalczyk and Kaczmarek, 2014 [84] has been collected from Gutmana Cave in the Gauja National Park [84]. In addition, Bartels et al. [85] described Mac. martini Bartels, Pilato, Lisi and Nelson, 2009 [86] from Gregorys Cave, North America. Nevertheless, one could think that cave invertebrates are more suitable for analysis, as the number of species is very low in comparison with to above ground habitats [5].

Up to now, tardigrades have been reported from 32 of the 82 Turkish provinces (see Table 2 for details). Among them, ten species have been described as endemic to Turkey (i.e., Cor. ceratophorus (Maucci, 1973) [10], Ech. dikenli Maucci, 1973 [10], Ech. osellai Maucci, 1975 [11], Ech. trojanus Maucci, 1973 [10], Urs. duranteae (Maucci, 1978) [12], Iso. macrodactylus (Maucci, 1978) [12], Gre. sismicus (Maucci, 1978) [12], Mil. beasleyi Kaczmarek, Jakubowska and Michalczyk, 2012 [9], Ita. placophorum Maucci, 1973 [10] and Ten. hystricogenitus (Maucci, 1978) [12]. In total, 54 valid species and one subspecies have been reported from Turkey. This number is quite inadequate when compared with other countries of smaller area (e.g., Romania ca 128, Poland ca. 102 and Italy ca. 233) [9,86-89]. Therefore, more samples are required to increase knowledge about distribution of tardigrades in Turkey.

Author Contributions: Methodology, D.B.; software, D.B.; validation, D.B. and A.A.; formal analysis, D.B. and A.A.; investigation, D.B. and A.A.; resources, D.B.; data curation, D.B.; writing一original draft preparation, D.B.; writing-review and editing, D.B.; visualization, D.B. All authors have read and agreed to the published version of the manuscript.

Funding: This research received no external funding.

Acknowledgments: We are grateful to Łukasz Kaczmarek for valuable comments and English improvements to this manuscript. We also wish to thank the Institute of Biotechnology at Ankara University for their contribution by providing technical and logistic support during our studies and the fieldwork.

Conflicts of Interest: The funders had no role in the design of the study; in the collection, analyses, or interpretation of data; in the writing of the manuscript, or in the decision to publish the results.

\section{References}

1. Uzun, A.; Zeybek, H. Akçakale Mağarası (Gümüşhane). TCD 1996, 31, 39-53. [CrossRef]

2. Aygen, T.; Demirel, S. Mağaralar ve Yeraltı Irmakları; DSİ Matbaası: Ankara, Turkey, Speleoloji, 1959.

3. Sür, A. Karstik Yerşekilleri ve Türkiye'den örnekler. TÜCAUM 1994, 3, 1-28.

4. Novak, T.; Perc, M.; Lipovšek, S.; Janžekovič, F. Duality of terrestrial subterranean fauna. Int. J. Speleol. 2012, 41, 181-188. [CrossRef]

5. Culver, D.C.; Deharveng, L.; Bedos, A.; Lewis, J.J.; Madden, M.; Reddell, J.R.; Sket, B.; Trontelj, P.; White, D. The mid-latitude biodiversity ridge in terrestrial cave fauna. Ecography 2006, 29, 120-128. [CrossRef]

6. Nelson, D.R.; Guidetti, R.; Rebecchi, L. Phylum Tardigrada. In Thorp and Covich's Freshwater Invertebrates, 4th ed.; Thorp, J.H., Rogers, D.C., Eds.; Elsevier: Amsterdam, The Netherlands, 2015; pp. 347-380.

7. Ramazzotti, G.; Maucci, W. Il Phylum Tardigrada. Terza edizione riveduta e corretta. Mem. Ist. Ital. Idrobiol. Dott. Marco Marchi 1983, 41, 1-1012.

8. Degma, P.; Guidetti, R.; Bertolani, R. Actual Checklist of Tardigrada Species, 36th ed.; Università di Modena e Reggio Emilia: Modena, Italy, 2019. [CrossRef]

9. Kaczmarek, Ł.; Jakubowska, N.; Michalczyk, Ł. Current knowledge on Turkish tardigrades with a description of Milnesium beasleyi sp. nov. (Eutardigrada: Apochela: Milnesiidae, the granulatum group). Zootaxa 2012, 3589, 49-64. [CrossRef]

10. Maucci, W. Tardigradi muscoli della Turchia. Mem. Mus. Civ. St. Nat. Verona 1973, 20, 169-221.

11. Maucci, W. Tardigradi muscoli della Turchia (secondo contributo). Boll. Mus. Civ. St. Nat. Verona 1975, 1, 255-275. 
12. Maucci, W. Tardigradi muscoli della Turchia (Terzo contributo). Boll. Mus. Civ. St. Nat. Verona 1978, 5, 111-140.

13. Maucci, W. I Pseudechiniscus del gruppo cornutus, con descrizione di una nuova specie (Tardigrada, Echiniscidae). Zesz. Nauk. Uniw. Jagellon. Prace Zool. 1979, 25, 107-124.

14. Maucci, W. Analisi preliminare di alcuni dati statistici sulla ecologia dei tardigradi muscicoli. Boll. Mus. Civ. St. Nat. Verona 1980, 7, 1-47.

15. Maucci, W. Analisi di alcune biocenosi relative a tardigradi muscicoli. Boll. Mus. Civ. St. Nat. Verona 1981, 8 , 67-83.

16. Maucci, W. Materiali per una revisione del genere Echiniscus Schultze, 1840. I: Il complesso blumi (Heterotardigrada, Echiniscidae). Boll. Mus. Civ. St. Nat. Verona 1985, 12, 109-139.

17. Morgan, C.I. An Annotated Catalogue of Tardigrada in the Collections of the Royal Scottish Museum, Edinburgh; Royal Scottish. Museum Information Series, Natural History: Edinburg, Scotland, 1977; Volume 5, pp. 1-29. ISSN 0307-5036.

18. Binda, M. Redescrizione di Macrobiotus echinogenitus Richters, 1904 e sul valore di buona specie di Macrobiotus crenulatus Richters, 1904 (Eutardigrada). Animalia 1988, 15, 201-210. [CrossRef]

19. Kharkevych, K.O.; Sergeeva, N. Deep-water Tardigrada of the Istanbul Strait's (Bosporus) outlet area of the Black Sea. Vestn. Zool. 2013, 47, 17-27. [CrossRef]

20. Ürkmez, D.; Ostrowska, M.; Roszkowska, M.; Gawlak, M.; Zawierucha, K.; Kristensen, R.M.; Kaczmarek, Ł. Description of Megastygarctides sezginii sp. nov. (Tardigrada: Arthrotardigrada: Stygarctidae) from the Turkish Black Sea coast and a key to the genus Megastygarctides. Mar. Biol. Res. 2018, 14, 1-16. [CrossRef]

21. Schultze, C.A.S. Echiniscus bellermanni, Animal Crustaceum, Macrobiotus hufelandii Affine. Apud G. Reimer Berl. 1840, 1-8.

22. Guidetti, R.; Rebecchi, L.; Bertolani, R.; Jönsson, K.I.; Møbjerg Kristensen, R.; Cesari, M. Morphological and molecular analyses on Richtersius (Eutardigrada) diversity reveal its new systematic position and lead to the establishment of a new genus and a new family within Macrobiotoidea. Zool. J. Linn. Soc. Lond. 2016, 178, 834-845. [CrossRef]

23. Haner, B.; Yılmaz, A.; Kürkçüoğlu, M.E.; Karadem, A. Mencilis (Bulak) mağarasında radon seviyesi ölçümleri. SDÜFENBED 2010, 14, 218-224. [CrossRef]

24. Özdemir, Ü. Mencilis Mağarası. DCD 2005, 10, 135-150.

25. Cetin, M.; Sevik, H.; Saat, A. Indoor air quality: The samples of Safranbolu Bulak Mencilis Cave. Fresen. Environ. Bull. 2017, 26, 5965-5970.

26. Dastych, H. Niesporczaki (Tardigrada) Tatrzańskiego Parku Narodowego; Naukowe, W.P., Ed.; Polska Akademia. Nauk. Monografie. Fauny Polski: Kraków, Poland, 1980; Volume 9, pp. 1-232.

27. Stec, D.; Smolak, R. An integrative description of Macrobiotus paulinae sp. nov. (Tardigrada: Eutardigrada: Macrobiotidae: Hufelandi group) from Kenya. Zootaxa 2015, 4052, 501-526. [CrossRef] [PubMed]

28. Perry, E.; Miller, W.R.; Kaczmarek, Ł. Recommended abbreviations for the names of genera of the phylum Tardigrada. Zootaxa 2019, 4608, 145-154. [CrossRef] [PubMed]

29. Guidetti, R.; Schill, R.; Bertolani, R.; Dandekar, T.; Wolf, M. New molecular data for tardigrade phylogeny, with the erection of Paramacrobiotus gen. nov. J. Zool. Syst. Evol. 2009, 47, 315-321. [CrossRef]

30. Doyère, L.M.F. Memoire sur les Tardigrades. Ann. Sci. Nat. Zool. 1840, 14, 269-362.

31. Richters, F. Isländische Tardigraden. Zool. Anz. 1904, 28, 373-377.

32. Spallanzani, L. Opuscules de Physique Animale et Végétale; Chirol, B., Ed.; Geneva, 1777; Volume 1, pp. 1-220. Available online: https://archive.hshsl.umaryland.edu/handle/10713/3327 (accessed on 5 March 2020).

33. Marcus, E. Zur Anatomie und Ökologie mariner Tardigraden. Zool. Jahrb. Abt. Syst. Ökol. Geogr. Tiere 1927, 53, 487-558.

34. Richters, F. Tardigrada. In Handbuch der Zoologie. Vol. by Kükenthal, W. and Krumbach, T.; de Gruyter, W., Ed.; Walter de Gruyter \& Co.: Leipzig/Berlin, Germany, 1926; Volume 3, pp. 58-61.

35. Thulin, G. Über die Phylogenie und das System der Tardigraden. Hereditas 1928, 11, 207-266. [CrossRef]

36. McInnes, S.J. Zoogeographic distribution of terrestrial/freshwater tardigrades from current literature. J. Nat. Hist. 1994, 28, 257-352. [CrossRef]

37. Guil, N.; Jørgensen, A.; Kristensen, R. An upgraded comprehensive multilocus phylogeny of the Tardigrada tree of life. Zool. Scripta 2019, 48, 120-137. [CrossRef]

38. Ehrenberg, C.G. Diagnoses novarum formarum. Ber. Akad. Wiss. Berl. 1853, 8, 526-533. 
39. Cagrı, T.; Duygu, B.; Seyda, E.F.; Gurbuzer, P.; Altindag, A. New Records for Tardigrada Species from the High Mountain Region in Turkey (Mount Verçenik, Rize). J. Limnol. Freshw. Fish. Res. 2019. [CrossRef]

40. Richters, F. Zwei neue Echiniscus-Arten. Zool. Anz. 1907, 31, 197-202.

41. Ramazzotti, G. Nuova varietà del Tardigrado Pseudechiniscus cornutus. Riv. Sci. Nat. Nat. 1943, 34, 89-90.

42. Renaud-Debyser, J. Études sur la faune interstitielle des Iles Bahamas. III. Tardigrades. Bull. Lab. Arago. Univ. Paris 1959, 10, 296-302.

43. De Zio Grimaldi, S.; D'Addabbo, M.G.; Sandulli, R.; D'Addabbo, R. Checklist of the Italian marine Tardigrada. Meiofauna Mar. 2003, 12, 97-135.

44. Gallo, M.; D’addabbo, R.; De Leonardis, C.; Sandulli, R.; Grimaldi, S.D.Z. The diversity of Indian Ocean Heterotardigrada. J. Limnol. 2007, 66, 60-64. [CrossRef]

45. Binda, M.G. Nuovi dati su tardigradi di Sicilia con descrizione di due nuove specie. Boll. Accad. Gioenia Sci. Nat. Catania 1969, 9, 623-633.

46. Iharos, G. Neue Tardigraden-Arten aus Ungarn. Acta Zool. Acad. Sci. Hung. 1966, 12, 111-122.

47. Richters, F. Nordische Tardigraden. Zool. Anz. 1903, 27, 168-172.

48. Marcus, E. Beiträge zur Tardigraden systematik. Zool. Jahrb. Abt. Anat. Ontog. Tiere 1930, 59, $363-386$.

49. Gassiorek, P.; Vončina, K.; Michalczyk, Ł. Echiniscus testudo (Doyère, 1840) in New Zealand: Anthropogenic dispersal or evidence for the 'Everything is Everywhere' hypothesis? New Zealand J. Zool. 2019, 46, 174-181. [CrossRef]

50. Murray, J. British Antarctic expedition 1907-1909, Reports on the scientific investigations. Biology 1910, 1, 83-187.

51. Murray, J. Arctiscoida. Proc. R. Ir. Acad. 1911, 31, 1-16.

52. Dastych, H. The Tardigrada of Poland. Monogr Fauny Pol. 1988, 16, 1-255.

53. Richters, F. Arktische Tardigraden. Fauna Arct. 1904, 3, 495-508.

54. Thulin, G. Beitrag zur Kenntnis der Tardigraden fauna Schwedens. Ark. Zool. 1911, 7, 1-60.

55. Jørgensen, A.; Møbjerg, N.; Kristensen, R.M. A molecular study of the tardigrade Echiniscus testudo (Echiniscidae) reveals low DNA sequence diversity over a large geographical area. J. Limnol. 2007, 66, 77-83. [CrossRef]

56. McInnes, S.J.; Michalczyk, Ł.; Kaczmarek, Ł. Annotated zoogeography of non-marine Tardigrada: Part IV: Africa. Zootaxa 2017, 4284, 1-74. [CrossRef]

57. Cuénot, L. Tardigrades. In Faune de France; Lechevalier, P., Ed.; Fédération Française des Sociétés de Sciences Naturelles: Paris, Frances, 1932; Volume 24, pp. 1-96.

58. Urbanowicz, C. Sur la variabilité de Macrobiotus oberhaeuseri. Bull. Biol. Fr. 1925, 59, 124-142.

59. Kaczmarek, Ł.; Michalczyk, Ł. Redescription of Hypsibius microps Thulin, 1928 and H. pallidus Thulin, 1911 (Eutardigrada: Hypsibiidae) based on the type material from the Thulin collection. Zootaxa 2009, 2275, 60-68. [CrossRef]

60. Tekatli, C.; Altindag, A. New Records for Tardigrada from Cyprus. North West. J. Zool. 2017, 13, 356-358.

61. Maucci, W. Tardigrada. Fauna Ital. Bologna Calderini 1986, 24, 1-388.

62. Schultze, K.A.S. Macrobiotus Hufelandii, Animal e Crustaceorum Classe Novum, Reviviscendi Post Diuturnam Asphyxiam et Ariditatem Potens; Curths, C.A., Ed.; Apud Carolus Curths: Berlin, Germany, 1834; pp. 165-169.

63. Maucci, W. Tardigradi nuovi della fauna italiana. Boll. Soc. Geol. Ital. 1954, 93, 576-585.

64. Binda, M.G.; Pilato, G. Tardigradi muscicoli di Sicilia (IV Nota). Boll. Sedute. Accad. Gioenia. Sci. Nat. Catania $1972,11,47-60$.

65. Murray, J. XXV-Arctic Tardigrada, collected by Wm. S. Bruce. Earth Environ. Sci. Trans. R. Soc. Edinb. 1907, 45, 669-681. [CrossRef]

66. Pilato, G.; Sperlinga, G. Tardigradi muscicoli di Sardegna. Animalia 1975, 2, 79-90.

67. Michalczyk, Ł.; Kaczmarek, Ł. A description of the new tardigrade Macrobiotus reinhardti (Eutardigrada: Macrobiotidae, harmsworthi group) with some remarks on the oral cavity armature within the genus Macrobiotus Schultze. Zootaxa 2003, 331, 1-24. [CrossRef]

68. Du Bois-Reymond Marcus, E. Sobre tardigrados Brasileiros. Com. Zool. Mus. Montev. 1944, 1, 1-19.

69. Plate, L. Beiträge zur Naturgeschichte der Tardigraden. Zool. Jahrb. 1888, 3, 487-550. [CrossRef]

70. Cuénot, L. Description d'un tardigrade nouveau de la faune francaise. C. R. Acad. Sci. III 1926, 182, 744-745.

71. Binda, M.; Pilato, G. Nuove osservazioni sui Tardigradi delle Isole Eolie. Boll. Sedute Accad. Gioenia Sci. Nat. Catania 1971, 10, 766-774. 
72. Binda, M.G.; Pilato, G. Le attuali conoscenze sulla fauna tardigradologica di alcue piccole isole circumsiciliane. Lav. So. Ital. Biogeogr. 1973, 3, 1-7.

73. Petersen, B. The Tardigrade fauna of Greenland. A faunistic study with some few ecological remarks. Medd. Grønl. 1951, 150, 5-94.

74. Mihelcic, F. Beitrag zur Systematik der Tardigraden. Arch. Zool. Ital. 1951, 36, 57-103.

75. Maucci, W. Un nuova Pseudechiniscus del Carso Triestino (Tardigrada, Scutechiniscidae). Atti Soc. Ital. Sci. Nat. 1952, 91, 127-130.

76. Renaud-Mornant, J. Occurrence of the Genus Tanarctus Renaud-Debyser, 1959 in North Eastern Atlantic waters with a description of T. ramazzottii n. sp. (Arthrotardigrada). Mem. Ist. Ital. Idrobiol. Pallanza 1975, 32, 325-332.

77. Iharos, G. Neuere Beiträge zur Kenntnis der Tardigraden-Fauna Ungarns. V. Opusc. Zool. Bp. 1964, 5, 57-67.

78. Mihelcic, F. Zwei neue Tardigraden aus der Gattung Hypsibius Thulin aus Osttirol (Österreich). Systematisches zur Gattung Hypsibius Thulin. Zool. Anz. 1959, 163, 254-261.

79. Zawierucha, K.; Kolicka, M.; Cytan, J. Contribution to the knowledge on the distribution of Echiniscus granulatus (Doyère, 1840) (Heterotardigrada) in Poland. Bad. Fizjogr. Ser. C. Zool. 2013, 53, 39-43. [CrossRef]

80. Arcidiacono, R. Contributo alla conoscenza dei Tardigradi dei Monti Nebrodi e descrizione di una nuova specie di Itaquascon. Boll. Sedute Accad. Gioenia Sci. Nat. Catania 1962, 7, 123-134.

81. Beasley, C.W.; Cleveland, A. Tardigrada from southern Yunnan province, People's Republic of China. Zool. J. Linn. Soc. 1996, 116, 239-243. [CrossRef]

82. Bartels, P.J.; Nelson, D.R.; Kaczmarek, Ł.; Michalczyk, Ł. Doryphoribius smokiensis, a new species of Eutardigrada (Hypsibiidae) from the Great Smoky Mountains National Park, TN, USA (North America). Zootaxa 2007, 1646, 59-65. [CrossRef]

83. Bartels, P.J.; Nelson, D.R.; Kaczmarek, L.; Michalczyk, L. Three new species and one new record of the genus Doryphoribius Pilato, 1969 (Tardigrada: Eutardigrada: Hypsibiidae) from the Great Smoky Mountains National Park (Tennessee, USA). J. Nat. Hist. 2008, 42, 2595-2608. [CrossRef]

84. Zawierucha, K.; Dziamięcki, J.; Jakubowska, N.; Michalczyk, Ł.; Kaczmarek, Ł. New tardigrade records for the Baltic states with a description of Minibiotus formosus sp. n. (Eutardigrada, Macrobiotidae). ZooKeys 2014, 408, 81-105. [CrossRef]

85. Bartels, P.J.; Pilato, G.; Lisi, O.; Nelson, D.R. Macrobiotus (Eutardigrada, Macrobiotidae) from the Great Smoky Mountains National Park, Tennessee/North Carolina, USA (North America): Two new species and six new records. Zootaxa 2009, 2022, 45-57. [CrossRef]

86. Ciobanu, D.A.; Moglan, I.; Zawierucha, K.; Kaczmarek, Ł. New records of terrestrial tardigrades (Tardigrada) from Ceahlău National Park with zoogeographical and taxonomical remarks on Romanian water bears. North West. J. Zool. 2014, 10, 5-21.

87. Nowak, B.; Stec, D. The first record of Macrobiotus vladimiri Bertolani, Biserov, Rebecchi and Cesari, 2011 (Tardigrada: Eutardigrada: Macrobiotidae: Hufelandi group) from Poland. Turk. J. Zool. 2017, 41, 558-567. [CrossRef]

88. Kaczmarek, Ł.; Gołdyn, B.; Czyż, M.; Michalczyk, Ł. First records of Isohypsibius pushkini Tumanov, 2003 (Tardigrada, Eutardigrada, Hypsibiidae) from Poland. Biol. Lett. 2010, 47, 81-85. [CrossRef]

89. Roszkowska, M.; Ostrowska, M.; Grobys, D.; Kmita, H.; Kaczmarek, Ł. Some Tardigrades from Italy, with an updated checklist of limno-terrestrial species from the country. Acta. Zool. Bulg. 2019, 71, 167-174.

(C) 2020 by the authors. Licensee MDPI, Basel, Switzerland. This article is an open access article distributed under the terms and conditions of the Creative Commons Attribution (CC BY) license (http://creativecommons.org/licenses/by/4.0/). 